DOI.

https://doi.org/10.22219/fths.v3i2

Received: April 2020

Accepted: Mei 2020

Available online: Juli 2020

\title{
Kajian Pembuatan Beras Analog Berbasis Tepung Komposit dengan Penambahan Konsentrasi Bubur Rumput Laut (Gracilaria sp.) dan Gliserol Monostearat
}

\author{
Damat $^{*}$, Rizma Amalia Natazza ${ }^{1}$, Vritta Amroini Wahyudi ${ }^{1}$ \\ ${ }^{1}$ Program Studi Teknologi Pangan, Fakultas Pertanian-Peternakan, Universitas Muhammadiyah \\ Malang, Malang, Indonesia \\ *Corresponding author email : damat@umm.ac.id
}

\begin{abstract}
Rice consumption is estimated to increase along with the increase in population every year. Analog rice is one alternative to functional food diversification and was expected to help reduce people's dependence on rice consumption. The addition of seaweed and glycerol monostearate in the study was intended to improve the shape of rice grains from previous studies which were sticky so that the shape of the rice was lost, enriching antioxidants and fiber from analog rice. The purpose of this study was to determine the interaction and effect of the addition of seaweed pulp extracts and glycerol monostearate to analog rice. The design of this study is a factorial randomized block design (RBD-F). Factor I is seaweed with 3 levels of concentration $\{1 \%, 2 \%$, 3\%\}, factor II is glycerol monostearate with 4 levels of concentration $\{1 \%, 2 \%, 3 \%$, 4\%?. The results of the study the highest value on the water content of the addition of seaweed $3 \%$ by $7.51 \%$; carbohydrate glycerol monostearate level of 1\% was $91.78 \%$; the antioxidant activity of rice and rice in seaweed concentration of $3 \%$ by $27.35 \%$ and $25.57 \%$; The highest value of rice fiber and rice in the treatment of Seaweed 3\% and GMS 3\% by $1.53 \%$ and $1.63 \%$. Organoleptic results in the form of appearance $(5.33=$ interesting), taste $(4.44=$ somewhat like $)$, fondness $(4.33=$ somewhat like $)$, aroma $(2.67=$ not fishy $)$, and texture $(2.33=$ not sticky $)$.

Keywords: analog rice, antioxidant activity, food fiber, seaweed porridge
\end{abstract}

\section{PENDAHULUAN}

Produksi padi di Indonesia tahun 2019 menurut Badan Pusat Statistik menurun dibanding tahun 2018 dari 33,94 juta ton menjadi 31,31 juta ton (Badan Pusat Statistik, 2019). Beras menjadi makanan pokok bagi sebagian besar masyarakat di Indonesia. Menurut Badan Pusat Statistik (2017), konsumsi beras padi pada tahun 2017 sebesar 29,13 juta ton dan diperkirakan akan meningkat seiring dengan penambahan jumlah penduduk Indonesia (Badan Pusat Statistik, 2017). Menurunnya produksi padi menjadi salah satu alasan pemerintah untuk melakukan impor beras. Upaya untuk mengurangi impor beras dan tingginya minat masyarakat Indonesia dalam mengkonsumsi beras adalah dengan diversifikasi pangan.

Diversifikasi pangan dapat dilakukan dengan memproduksi beras analog yang diolah dari bahan baku umbi-umbian yang keberadaannya melimpah di Indonesia. Beras analog merupakan beras tiruan yang berbahan baku tepung- 
tepungan selain beras dan terigu yang bersifat fungsional karena kandungan kimia dan gizinya dapat disesuaikan dengan tujuan yang ingin dicapai. Beras analog diharapkan dapat menjadi salah satu alternatif diversifikasi pangan di Indonesia sehingga dapat menekan angka impor beras (Budijanto, 2012). Bahan baku dalam pembuatan beras analog harus dilakukan dengan cermat karena akan menentukan kandungan gizi dan karakteristik beras yang akan dicapai. Sumber karbohidrat berbasis pangan lokal seperti tepung jagung, pati garut, pati sagu aren, dan sumber lainnya memiliki nilai gizi yang tinggi serat pangan, lemak, fenol dan pati resisten (Noviasari, 2017). Hal tersebut membuat beras analog memiliki sifat fungsional yang bermanfaat bagi kesehatan.

Penambahan bubur rumput laut pada beras analog dikarenakan kandungan agar pada rumput laut dikenal sebagai sumber serat dan antioksidan yang baik bagi tubuh (Fauzi, 2017). Sifat gelling agent pada rumput laut juga diharapkan dapat menjadi perekat agar beras yang dihasilkan lebih kokoh dan tidak mudah rapuh. Bahan tambahan lain yang dibutuhkan dalam pembuatan beras analog adalah gliserol monostearat (GMS) 2\% dan air 50\% (Budijanto, 2012). Penggunaan GMS pada beras analog berfungsi sebagai pelumas pada barel saat proses ekstrusi berlangsung, membuat ekstrudat tidak saling lengket dan mengurangi pengembangan produk (Kaur, 2005; Noviasari, 2017). Tujuan dari penelitian ini adalah menganalisis pengaruh penambahan bubur rumput laut dan gliserol monosterat terhadap sifat kimia beras dan organoleptik nasi analog.

\section{METODE PENELITIAN}

\section{Bahan}

Bahan baku yang dibutuhkan dalam penelitian pembuatan beras analog antara lain tepung jagung, tepung mocaf, dan sagu aren yang didapatkan dari Pasar Tradisional Malang dan pati garut yang didapatkan dari petani di Kecamatan Poncokusumo Kabupaten Malang, gliserol monostearat, rumput laut gracilaria sp. kering berwarna coklat kehitaman yang didapat dari Brebes, dan air.

Alat

Alat yang dibutuhkan dalam penelitian ini antara lain steamer 'oxone', ekstruder 'barata Indonesia BA-005', pengering kabinet, sentrifuge 'Calieys', timbangan analitik 'Ohaus' tipe PA413, hotplate 'Maspion S-301', dan digital thermostat waterbath HH- 4.

\section{Pembuatan Bubur Rumput Laut}

Tahapan ini memodifikasi pembuatan bubur rumput laut yang terdiri dari perendaman, penghalusan, dan pemasakan yang mengacu pada penelitian Wonggo (2010). 


\section{Pembuatan Beras Analog}

Pembuatan beras analog diawali dengan melakukan penimbangan bahan baku adonan seperti tepung jagung $40 \%$, sagu aren $30 \%$, pati garut $15 \%$, mocaf $15 \%$, air $20 \%$, bubur rumput laut dan GMS sesuai perlakuan. Kemudian dilakukan pengukusan selama 15 menit. Kemudian dilanjutkan proses ekstruksi dengan menggunakan mesin ekstruder. Setelah menjadi butiran beras analog langkah selanjutnya beras analog dikeringkan menggunakan cabinet dryer suhu $50^{\circ} \mathrm{C}$ selama $\pm 24 \mathrm{jam}$. Kemudian, dilakukan pengayakan guna memisahkan butiran beras (Noviasari, 2017). Beras analog yang dihasilkan kemudian dilakukan analisa.

\section{Parameter Penelitian}

Parameter penelitian yang digunakan antara lain uji kimia dan organoleptik. Pengujian sifat kimia berupa kadar air (AOAC, 2005), kadar abu (AOAC, 2005), kadar lemak (AOAC, 2005), kadar protein metode biuret (Martono, 2012), kadar karbohidrat by difference (AOAC, 2005), antioksidan beras Radical Scavenning Activity (Agus, 2009), antioksidan nasi Radical Scavenning Activity (Agus, 2009), serat pangan beras (AOAC, 2005), dan serat pangan nasi (AOAC, 2005). Setelah pengujian kimia dilakukan, dilanjutkan dengan pengujian organoleptik (Masli, 2007) pada nasi analog meliputi rasa, aroma, tekstur, kenampakan, dan kesukaan.

\section{Rancangan Percobaan dan Analisa Data}

Rancangan percobaan yang diterapkan dalam penelitian ini adalah Rancangan Acak Kelompok (RAK) Faktorial. Faktor 1 yang digunakan adalah penambahan bubur rumput laut sebanyak 3 level (1\%, 2\%, 3\%). Faktor 2 yang digunakan adalah gliserol monostearat (GMS) sebanyak 4 level (1\%, 2\%, 3\%, $4 \%)$. Bahan baku yang digunakan bersifat homogen yaitu tepung jagung $40 \%$, sagu aren $30 \%$, pati garut $15 \%$, mocaf $15 \%$ dan air $20 \%$ dari total berat bahan baku. Ulangan pada masing-masing perlakuan akan dilakukan sebanyak 2 kali.

Pengolahan data dilakukan dengan menggunakan analisis ragam pada taraf $5 \%$ dan 1\%. Selanjutnya bila terjadi beda nyata atau interaksi pada masing-masing perlakuan maka data yang sudah diperoleh akan dilanjutkan dengan uji pembeda menggunakan uji DMRT (Duncan's Multiple Range Test) pada taraf $5 \%$, dan $1 \%$.

\section{HASIL DAN PEMBAHASAN \\ Karakteristik Bahan Baku}

Bahan baku yang diuji adalah tepung jagung, sagu aren, pati garut, mocaf, dan bubur rumput laut. Hasil analisis bahan baku beras analog meliputi kadar air, kadar abu, kadar protein, kadar lemak, dan kadar karbohidrat. Hasil analisis dapat dilihat pada Tabel 1 
Tabel 1. Sifat Kimia Bahan Baku Beras Analog

\begin{tabular}{lccccc}
\hline $\begin{array}{c}\text { Komponen } \\
\text { Kimia (\%) }\end{array}$ & $\begin{array}{c}\text { Tepung } \\
\text { jagung }\end{array}$ & $\begin{array}{c}\text { Sagu } \\
\text { aren }\end{array}$ & Pati garut & MOCAF & $\begin{array}{c}\text { Bubur rumput } \\
\text { laut }\end{array}$ \\
\hline Kadar Air & 9,18 & 15,28 & 11,85 & 12,51 & 87,30 \\
Kadar Abu & 0,47 & 0,65 & 0,44 & 0,32 & 0,19 \\
Kadar Protein & 0,97 & 0,86 & 0,38 & 0,71 & 3,55 \\
Kadar Lemak & 3,46 & 1,98 & 1,29 & 2,37 & 2,84 \\
Kadar & 85,92 & 81,23 & 86,03 & 84,09 & 6,12 \\
Karbohidrat & & & & & \\
\hline
\end{tabular}

Kadar air merupakan suatu parameter yang penting untuk produk pangan karena dapat mempengaruhi umur simpan suatu produk. Berdasarkan Tabel 1 kadar air bubur rumput laut yang paling tinggi, Kadar air yang tinggi menyebabkan suatu mutu produk memiliki umur simpan yang relatif singkat dikarenakan sangat mudah ditumbuhi oleh mikroba. Hal ini didukung oleh pernyataan Winarno (2008) suatu produk yang memiliki kadar air rendah akan memiliki mutu yang lebih baik dikarenakan dapat menurunkan aktivitas air (Aw) sehingga memperkecil tumbuhnya mikroba. Nilai kadar abu berhubungan dengan kandungan mineral suatu bahan atau bahan anorganik lainnya (Fauzi, 2017). Kadar abu selain untuk mengetahui kandungan mineral juga dapat digunakan untuk mengetahui tingkat kemurnian tepung karena menurut Ginting (2011), semakin tinggi kadar abu pada tepung akan menghasilkan warna tepung yang semakin gelap. Nilai kadar abu yang semakin rendah pada tepung menandakan kualitasnya semakin baik karena kadar abu mempengaruhi tingkat kestabilan adonan (Lopulalan, 2016).

Kadar protein pada tepung dan pati bahan baku beras analog hanya berkisar antara 0,38\%-0,97\%, sedangkan kadar protein bubur rumput laut sekitar 3,55\% hal ini menunjukkan bahwa kadar protein tergantung pada asam amino yang terdapat di dalamnya, yang merupakan bagian terkecil dalam protein tersebut. Protein hewani diketahui memiliki nilai lebih tinggi dari pada protein nabati (Muchtadi dan Sugiyono, 2013). Kadar lemak tertinggi dari bahan baku berasa analog yakni pada tepung jagung sebesar 3,46\%. Tingginya kadar lemak pada tepung jagung diharapkan mampu mengurangi nasi menjadi tidak terlalu lengket satu sama lain serta diharapkan mampu memperbaiki tekstur beras (Widara, 2012). Karbohidrat memiliki peranan penting dalam terbentuknya karakteristik suatu produk seperti tekstur, warna, aroma dan kenampakan. Karbohidrat digolongkan menjadi dua jenis yakni karbohidrat yang dapat dicerna seperti (monosakarida, disakarida, dekstrin dan pati) dan karbohidrat yang tidak dapat dicerna (selulosa, hemiselulosa, dan serat) (Andarwulan, 2011). 


\section{Karakteristik Kimia Beras Analog}

Tabel 2. Hasil Analisis Kimia Beras Analog

\begin{tabular}{cccccccc}
\hline $\begin{array}{c}\text { Perlakua } \\
\text { n }\end{array}$ & $\begin{array}{c}\text { Kada } \\
\text { r Air } \\
(\%)\end{array}$ & $\begin{array}{c}\text { Kada } \\
\text { r Abu } \\
(\%)\end{array}$ & $\begin{array}{c}\text { Kada } \\
\text { Lema } \\
\text { k (\%) }\end{array}$ & $\begin{array}{c}\text { Kadar } \\
\text { Protei } \\
\text { n } \%)\end{array}$ & $\begin{array}{c}\text { Kadar } \\
\text { Karbohidr } \\
\text { at (\%) }\end{array}$ & $\begin{array}{c}\text { Antioksid } \\
\text { an beras } \\
(\%)\end{array}$ & $\begin{array}{c}\text { Antioksid } \\
\text { an beras } \\
(\%)\end{array}$ \\
\hline RL 1\% & $6,91^{\mathrm{a}}$ & $0,49^{\mathrm{a}}$ & $1,68^{\mathrm{a}}$ & $0,71^{\mathrm{a}}$ & $90,21^{\mathrm{a}}$ & $19,90^{\mathrm{a}}$ & $11,05^{\mathrm{a}}$ \\
RL 2\% & $6,81^{\mathrm{a}}$ & $0,55^{\mathrm{a}}$ & $1,53^{\mathrm{a}}$ & $0,68^{\mathrm{a}}$ & $90,42^{\mathrm{a}}$ & $22,83^{\mathrm{b}}$ & $18,03^{\mathrm{b}}$ \\
RL 3 \% & $7,51^{\mathrm{b}}$ & $0,48^{\mathrm{b}}$ & $1,52^{\mathrm{a}}$ & $0,64^{\mathrm{a}}$ & $89,85^{\mathrm{a}}$ & $27,35^{\mathrm{c}}$ & $25,57^{\mathrm{c}}$ \\
\hline GMS 1\% & $6,54^{\mathrm{a}}$ & $0,47^{\mathrm{a}}$ & $0,50^{\mathrm{a}}$ & $0,72^{\mathrm{b}}$ & $91,78^{\mathrm{c}}$ & $23,08^{\mathrm{ab}}$ & $15,39^{\mathrm{a}}$ \\
GMS 2\% & $7,07^{\mathrm{a}}$ & $0,51^{\mathrm{a}}$ & $1,18^{\mathrm{b}}$ & $0,72^{\mathrm{b}}$ & $90,52^{\mathrm{b}}$ & $21,38^{\mathrm{a}}$ & $17,98^{\mathrm{ab}}$ \\
& $\mathrm{b}^{\mathrm{b}}$ & & & & & & \\
GMS 3\% & $7,17^{\mathrm{b}}$ & $0,59^{\mathrm{b}}$ & $1,68^{\mathrm{c}}$ & $0,66^{\mathrm{ab}}$ & $89,90^{\mathrm{b}}$ & $24,56^{\mathrm{b}}$ & $20,04^{\mathrm{b}}$ \\
GMS 4\% & $7,51^{\mathrm{b}}$ & $0,48^{\mathrm{a}}$ & $2,96^{\mathrm{d}}$ & $0,61^{\mathrm{a}}$ & $88,43^{\mathrm{a}}$ & $24,42^{\mathrm{b}}$ & $19,45^{\mathrm{b}}$ \\
\hline
\end{tabular}

Keterangan: RL = Bubur rumput laut, GMS = Gliserol monosterat

Angka-angka yang diikuti huruf yang sama menunjukkan tidak berbeda nyata menurut uji Duncan pada taraf $5 \%$

\section{Kadar Air}

Berdasarkan analisa ragam menunjukkan hasil bahwa tidak ada interaksi antara penambahan bubur rumput laut dan GMS terhadap kadar air beras analog. Seiring dengan semakin banyaknya bubur rumput laut yang ditambahkan menyebabkan kadar air beras analog juga meningkat, hal ini dapat dikarenakan rumput laut memiliki kandungan senyawa hidrokoloid yang bersifat hidrofilik yakni mudah mengikat air. Hal ini sesuai dengan literatur Princestasari dan Amalia (2015) bahwa semakin tinggi penambahan konsentrasi rumput laut akan menghasilkan kadar air semakin besar karena rumput laut bersifat hidrokoloid. Semakin tinggi penambahan konsentrasi GMS menyebabkan kadar air pada beras analog juga semakin meningkat. Hal ini disebabkan karena GMS memiliki gugus hidrofilik yang mana memiliki kemampuan untuk menyerap air. Hal ini disebabkan karena GMS mampu menghalangi bergabungnya molekul-molekul pati dengan protein sehingga gugus $\mathrm{OH}$ bebas pada GMS yang berikatan jumlahnya menjadi relatif lebih meningkat (Winarti, 2017).

\section{Kadar Abu}

Berdasarkan hasil analisa ragam menunjukkan bahwa tidak terdapat interaksi antara penambahan bubur rumput laut dan GMS, sedangkan perbedaan konsentrasi bubur rumput laut dan GMS berpengaruh nyata terhadap kadar abu beras analog. Rumput laut kaya akan mineral, dimana mineral sendiri merupakan indikator dari kadar abu (Feri, 2006). Semakin 
rendahnya nilai kadar abu akibat penambahan rumput laut menurut Agusman (2014) karena rumput laut mengandung mineral natrium, iodium dan kalium. Sedangkan, rendahnya kadar abu pada beras analog kemungkinan dikarenakan banyaknya mineral yang rusak dan hilang selama proses pembuatan beras analog. Diketahui semakin tinggi konsentrasi penambahan GMS kandungan kadar abu juga semakin meningkat. Hal ini sesuai dengan pernyataan Hardiyan (2018) bahwa semakin tinggi konsentrasi GMS yang ditambahkan, maka kadar abu beras analog semakin meningkat

\section{Kadar Lemak}

Berdasarkan hasil analisa ragam diketahui bahwa tidak terdapat interaksi antara penambahan GMS dan penambahan rumput laut terhadap kadar lemak beras analog. Hasil analisis statistik menunjukkan tidak adanya pengaruh dari penambahan konsentrasi rumput terhadap kadar lemak beras analog. Hal ini sesuai dengan penelitian Muslikatin (2012), bahwa penambahan tepung rumput laut pada beras analog sebanyak 3-7\% tidak berpengaruh nyata, kadar lemak beras analog Muslikatin berkisar antara 0,34-0,62\%. semakin besar penambahan GMS maka nilai kadar lemak juga semakin besar. Hal ini dapat dikarenakan GMS sendiri merupakan surfaktan non-ionik yang biasanya digunakan sebagai stabilizer atau emulsifier oleh industri pangan di Indonesia yang salah satu bahan baku pembuatan GMS adalah lemak yang diperoleh dari minyak sawit (Nurcahyani, 2018). Kadar lemak yang rendah pada beras analog memiliki kelebihan yakni beras menjadi tidak mudah tengik.

\section{Kadar Protein}

Berdasarkan hasil analisa ragam didapatkan hasil bahwa tidak terdapat interaksi antara penambahan bubur rumput laut GMS terhadap kadar protein beras analog. Penambahan rumput laut juga tidak berpengaruh nyata terhadap kadar protein beras analog, hal ini dapat di akibatkan kandungan rumput laut dipengaruhi oleh lokasi dan kondisi penangkaran rumput laut, dan umur panen rumput laut (Dewi dan Susanto, 2011). Penambahan GMS menunjukkan tidak berpengaruh nyata terhadap nilai kadar protein secara statistik. Hal ini dikarenakan GMS bukan tersusun dari fraksi protein, hal ini sesuai dengan pendapat Hidayat (2006) bahwa variasi penambahan GMS pada produk pangan tidak memberikan pengaruh karena GMS sendiri tersusun oleh asam stearat bukan fraksi protein.

\section{Kadar Karbohidrat by difference}

Berdasarkan hasil analisa ragam yakni tidak terdapat interaksi antara GMS dan rumput laut. Hasil analisis statistik penambahan bubur rumput laut 1-3\% pada beras analog diketahui tidak berpengaruh nyata terhadap kadar karbohidrat. Kadar karbohidrat beras analog pada penambahan bubur rumput 
laut berkisar antara 89-85-90,42\% hal ini selaras dengan hasil penelitian Muslikatin (2012) penambahan rumput laut 3-7\% tidak berpengaruh nyata dengan nilai kadar karbohidrat berkisar antara 79,57-81,82\%. Semakin tinggi penambahan GMS maka nilai kadar karbohidrat menjadi semakin menurun. Hal ini sesuai tidak sesuai dengan pernyataan Winarti (2017) bahwa GMS memiliki fungsi mencegah hilangnya amilosa yang merupakan bagian dari pati selama terjadinya proses pemanasan dikarenakan rantai molekul GMS akan bereaksi dengan molekul amilosa secara heliks.

\section{Antioksidan Beras}

Berdasarkan hasil analisa ragam tidak terdapat interaksi antara penambahan bubur rumput laut dan GMS. Penambahan rumput laut berpengaruh nyata terhadap kadar aktivitas antioksidan beras analog. diketahui semakin tinggi penambahan konsentrasi rumput laut maka nilai aktivitas antioksidan juga semakin meningkat. Hal ini dikarenakan rumput laut merupakan salah satu sumber antioksidan alami, sehingga apabila semakin tinggi konsentrasi yang ditambahkan maka nilai aktivitasnya juga akan meningkat. Hal ini didukung oleh pernyataan Nawaly (2013), Senyawa bioaktif alami yang berasal dari rumput laut seperti pigmen karotenoid berupa fukosantin dan B-karoten; fenol dan turunannya; pigmen fikobilin; sulfat polisakarida; dan vitamin (C, E dan prekursor vitamin A) memiliki kemampuan untuk menetralkan radikal bebas pada tubuh manusia dengan kata lain berperan sebagai antioksidan.

\section{Antioksidan Nasi}

Berdasarkan analisa ragam tidak terdapat interaksi anatara penambahan gliserol monostearat dan rumput laut. Penambahan rumput laut berpengaruh nyata terhadap aktivitas antioksidan nasi. Penambahan GMS menurut data statistik tidak berpengaruh nyata terhadap kadar antioksidan nasi. Berdasarkan tabel diatas juga diketahui bahwa semakin tinggi penambahan rumput laut maka aktivitas antioksidan nasi juga semakin meningkat hal ini dapat dikarenakan rumput laut berperan sebagai antioksidan alami. Hal ini didukung oleh pernyataan Nawaly (2013), rumput laut menjadi salah satu sumber antioksidan alami karena mengandung senyawa bioaktif seperti senyawa fenol dan turunannya, karotenoid, sulfat polisakarida, dan vitamin.

\section{Kadar Serat Beras Dan Nasi}

Berdasarkan hasil analisis ragam diketahui penambahan bubur rumput laut dan GMS berinteraksi terhadap kadar serat beras dan nasi yang dapat dilihat pada Tabel 3 . 
Tabel 3 Nilai Kadar Serat Beras dan Nasi

\begin{tabular}{ccc}
\hline Perlakuan & Kadar Serat Beras (\%) & Kadar Serat Nasi (\%) \\
\hline R1G1 & $0,44^{\mathrm{a}}$ & $0,31^{\mathrm{ab}}$ \\
R1G2 & $0,62^{\mathrm{abc}}$ & $0,45^{\mathrm{abc}}$ \\
R1G3 & $0,54^{\mathrm{ab}}$ & $0,21^{\mathrm{a}}$ \\
R1G4 & $0,72^{\mathrm{bcd}}$ & $0,37^{\mathrm{ab}}$ \\
R2G1 & $0,89^{\text {def }}$ & $0,64^{\mathrm{bc}}$ \\
R2G2 & $0,81^{\text {cde }}$ & $0,68^{\mathrm{bc}}$ \\
R2G3 & $0,86^{\text {def }}$ & $0,59^{\mathrm{bc}}$ \\
R2G4 & $0,97^{\mathrm{efg}}$ & $0,64^{\mathrm{bc}}$ \\
R3G1 & $1,06^{\mathrm{fg}}$ & $0,80^{\mathrm{c}}$ \\
R3G2 & $1,09^{\mathrm{g}}$ & $1,25^{\mathrm{d}}$ \\
R3G3 & $1,53^{\mathrm{h}}$ & $1,63^{\mathrm{e}}$ \\
R3G4 & $1,35^{\mathrm{h}}$ & $1,22^{\mathrm{d}}$ \\
\hline
\end{tabular}

Angka-angka yang diikuti huruf yang sama menunjukkan tidak berbeda nyata menurut uji Duncan pada taraf $5 \%$

Berdasarkan tabel diatas dapat diketahui bahwa semakin tinggi konsentrasi bubur rumput laut yang ditambahkan maka nilai kadar serat baik pada beras maupun nasi yang dihasilkan juga semakin tinggi, hal ini membuktikan bahwa rumput laut merupakan salah satu sumber serat alami. Hal tersebut sesuai dengan penelitian Fauzi (2017) yang menyatakan bahwa semakin tinggi penambahan konsentrasi rumput laut dan tepung agar-agar menghasilkan nilai kadar serat yang semakin besar. Menurut Setiawati (2014) bahwa beras dan nasi analog yang ditambahkan dengan rumput laut selain sebagai sumber pangan juga bermanfaat secara fungsional, antara lain makanan sumber serat. Penambahan GMS berpengaruh terhadap kadar serat karena GMS dapat berikatan dengan amilosa secara heliks sehingga molekul amilosa dapat tertahan selama proses pemanasan (Winarti, 2017).

Menurut Damat dkk (2018), serat termasuk pati resisten (RS) yang diketahui memiliki kelebihan. RS diketahui tidak tercerna di dalam usus halus, akan tetapi akan terfermentasi di dalam usus besar dan menghasilkan asam lemak rantai pendek SCFA (short chain fatty acid). SCFA dapat memberikan efek yang menyehatkan bagi kolon. Kadar serat dapat dilakukan dengan cara modifikasi pati. Pati garut yang dimodifikasi, baik modifikasi dengan cara fisik diketahui dapat meningkatkan kadar total serat makanan sekitar tiga hingga empat kali lebih besar dari pati garut alami (Damat dkk, 2019). 


\section{Organoleptik Nasi Analog}

Berdasarkan hasil analisis ragam diketahui penambahan bubur rumput laut dan GMS berinteraksi terhadap kadar serat beras dan nasi yang dapat dilihat pada Tabel 4. Keterangan skor nilai mulai dari 1-7 adalah sebagai berikut sangat tidak menarik, tidak menarik, agak tidak menarik, agak menarik, menarik, sangat menarik, dan amat sangat menarik.

Tabel 4. Nilai Rerata Kenampakan dan Tekstur Nasi Analog

\begin{tabular}{ccc}
\hline Perlakuan & Rata-Rata Kenampakan Nasi (\%) & Rata - Rata Tekstur Nasi (\%) \\
\hline R1G1 & $4,33^{\text {fg }}$ & $3,00^{\mathrm{abc}}$ \\
R1G2 & $3,00^{\mathrm{bcd}}$ & $3,00^{\mathrm{abc}}$ \\
R1G3 & $2,33^{\mathrm{ab}}$ & $5,00^{\mathrm{d}}$ \\
R1G4 & $2,67^{\mathrm{abc}}$ & $5,00^{\mathrm{d}}$ \\
R2G1 & $5,33^{\mathrm{h}}$ & $2,33^{\mathrm{a}}$ \\
R2G2 & $3,33^{\mathrm{cde}}$ & $2,33^{\mathrm{a}}$ \\
R2G3 & $3,67^{\text {def }}$ & $3,33^{\mathrm{bc}}$ \\
R2G4 & $2,00^{\mathrm{a}}$ & $5,00^{\mathrm{d}}$ \\
R3G1 & $5,00^{\mathrm{gh}}$ & $2,67^{\mathrm{ab}}$ \\
R3G2 & $4,00^{\mathrm{ef}}$ & $3,00^{\mathrm{abc}}$ \\
R3G3 & $3,67^{\mathrm{def}}$ & $3,67^{\mathrm{c}}$ \\
R3G4 & $2,00^{\mathrm{a}}$ & $4,67^{\mathrm{d}}$ \\
\hline
\end{tabular}

Angka-angka yang diikuti huruf yang sama menunjukkan tidak berbeda nyata menurut uji Duncan pada taraf $5 \%$

Kenampakan nasi analog menunjukkan semakin tinggi nilainya, maka semakin menarik yakni pada perlakuan Rumput laut $2 \%$ dan GMS 1\%. Hal ini sesuai dengan hasil penelitian Hardiyan (2018) bahwa sampel yang paling disukai adalah sampel dengan konsentrasi GMS paling rendah sebesar 1\%. GMS juga memberikan pengaruh yang cukup signifikan terhadap kenampakan dari beras analog karena GMS berperan dalam memperbaiki produk yang rusak selama proses ekstrusi berlangsung (Hardiyan, 2018). Bubur rumput laut diketahui mengandung agar yang jika terkena panas akan membentuk gel sehingga membuat kenampakan nasi menjadi lebih baik dikarenakan teksturnya yang tidak lembek. Hal ini sesuai dengan pernyataan Fauzi (2017) yang menyatakan bahwa rumput laut mengandung agar yang dapat membentuk gel yang kemudian mempengaruhi terhadap tekstur beras dan nasi yang dihasilkan (Fauzi, 2017).

Tekstur nasi beras analog yang dikehendaki adalah pera dan tidak lengket atau menggumpal. Berdasarkan Tabel 4 juga dapat dilihat bahwa semakin tinggi penambahan GMS maka tekstur nasi beras analog semakin lengket. Hal ini tidak sesuai dengan pendapat Kuswardani (2008) bahwa 
penggunaan GMS dapat membuat tekstur kompak dan kenyal pada produk. Semakin tinggi penambahan konsentrasi GMS menyebabkan lapisan film dan tekstur yang terbentuk semakin kokoh. Hal ini menyebabkan penambahan GMS dapat meningkatkan daya elastisitas pada produk yang dihasilkan (Kuswardani, 2008). Penggunaan gliserol monostearat 1\% pada produk beras analog ini sudah menghasilkan sifat nasi yang pera, karena semakin tinggi konsentrasi yang ditambahkan justru membuat sifat pera nasi berkurang dan cenderung lengket dapat dilihat pada Gambar 1.

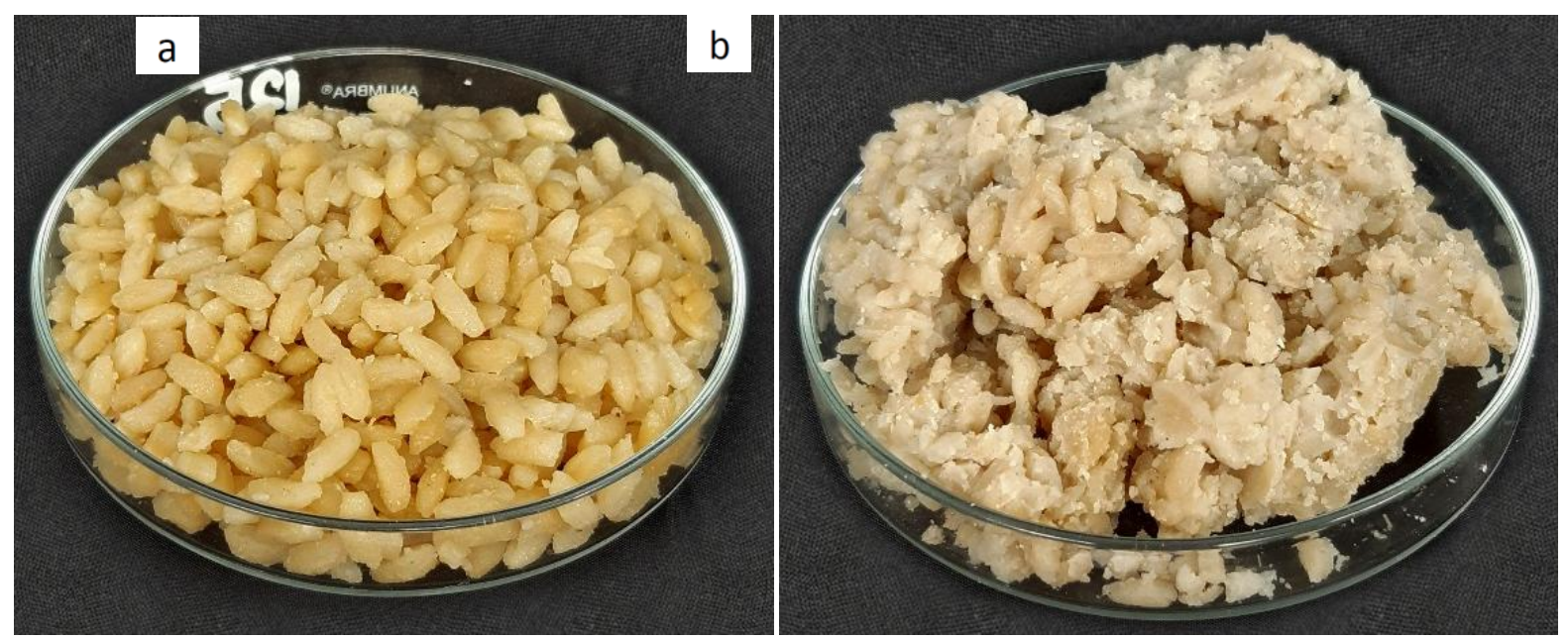

Gambar 1. Kenampakan dan Tekstur Nasi Analog a) perlakuan rumput laut 2\% GMS 1\% b) perlakuan rumput laut 2\% GMS 4\%

\section{Rasa Aroma Dan Kesukaan Nasi Analog}

Berdasarkan hasil analisa ragam diketahui tidak ada interaksi antara rumput laut dan GMS pada rasa, aroma, dan kesukaan nasi analog. Nilai rerata dapat dilihat pada Tabel 5. Keterangan skor nilai mulai dari 1-7 adalah sebagai berikut sangat tidak suka, tidak suka, agak tidak suka, agak suka, suka, sangat suka, dan amat sangat suka.

Hasil statistik penambahan bubur rumput laut diketahui tidak bepengaruh nyata terhadap rasa nasi. Hal ini sesuai dengan penelitian Agusman (2014), bahwa beras analog dengan penambahan rumput laut $7 \%$ tidak berpengaruh terhadap rasa nasi karena menghasilkan rasa nasi yang kurang enak dan cenderung hambar. Rasa nasi beras analog dengan penambahan GMS 1\% memiliki nilai 4,44 yang artinya agak disukai oleh panelis. Semakin tinggi penambahan konsentrasi GMS rasa dari nasi beras analog semakin tidak disukai oleh panelis. Hal ini dapat dikarenakan kenampakan dan tekstur nasi yang semakin lengket sehingga rasa dari nasi beras analog menjadi tidak sukai. 
Hal ini tidak sesuai dengan pernyataan Kuswardani (2008) penambahan GMS dapat meningkatkan daya elastisitas pada produk yang dihasilkan.

Tabel 5. Nilai Rasa, Aroma, dan Kesukaan Nasi Analog

\begin{tabular}{lccc}
\hline Perlakuan & Rasa Nasi (\%) & Aroma Nasi (\%) & Kesukaan Nasi (\%) \\
\hline RL 1\% & $3,42^{\mathrm{a}}$ & $3,08^{\mathrm{a}}$ & $3,50^{\mathrm{a}}$ \\
RL 2\% & $3,75^{\mathrm{a}}$ & $3,08^{\mathrm{a}}$ & $3,67^{\mathrm{a}}$ \\
RL 3 \% & $3,75^{\mathrm{a}}$ & $3,17^{\mathrm{a}}$ & $3,67^{\mathrm{a}}$ \\
GMS 1\% & $4,44^{\mathrm{c}}$ & $2,67^{\mathrm{a}}$ & $4,33^{\mathrm{c}}$ \\
GMS 2\% & $4,00^{\mathrm{b}}$ & $3,11^{\mathrm{ab}}$ & $4,11 \mathrm{~b}^{\mathrm{c}}$ \\
GMS 3\% & $3,78^{\mathrm{b}}$ & $3,11^{\mathrm{ab}}$ & $3,67^{\mathrm{b}}$ \\
GMS 4\% & $2,33^{\mathrm{a}}$ & $3,56^{\mathrm{b}}$ & $2,33^{\mathrm{a}}$ \\
\hline
\end{tabular}

Keterangan: RL $=$ Bubur rumput laut, GMS = Gliserol monosterat Angka-angka yang diikuti huruf yang sama menunjukkan tidak berbeda nyata menurut uji Duncan pada taraf $5 \%$

Hasil statistik penambahan bubur rumput laut tidak berpengaruh nyata terhadap aroma nasi analog. Nasi dengan penambahan bubur rumput laut memiliki skor 3,0-3,17 (agak tidak amis). Hal ini sesuai dengan penelitian Agusman (2014) bahwa penambahan rumput laut sampai 7\% tidak berpengaruh nyata terhadap aroma nasi. penambahan GMS membuat aroma nasi menjadi tidak terasa amis yang diakibatkan oleh rumput laut. Berkurangnya aroma amis dari rumput laut ini dapat dikarenakan semakin tinggi penambahan GMS maka daya rehidrasi produk menjadi lebih rendah sehingga aroma pada rumput laut menjadi lebih tersamarkan. Hal ini sesuai dengan pernyataan Winarti (2017) bahwa semakin tinggi penambahan GMS menyebabkan menurunnya daya rehidrasi, hal ini dikarenakan kemampuan GMS membentuk kompleks tidak larut air dengan amilosa sehingga menghalangi masuknya air menjadikan daya rehidrasi menurun (Winarti, 2017).

Berdasarkan hasil statistik diketahui penambahan bubur rumput laut tidak berpengaruh nyata terhadap kesukaan nasi. Nilai kesukaan nasi beras analog tertinggi yakni pada penambahan GMS 1\%. Hal ini dapat dikarenakan kenampakan, tekstur, bentuk, aroma dan rasa nasi yang lebih baik dan mendekati beras sosoh yang disukai oleh panelis. Semakin tinggi penambahan konsentrasi GMS kesukaan pada nasi beras analog semakin menurun. Hal ini dapat dikarenakan penambahan GMSl yang terlalu banyak menjadikan tekstur nasi yang lengket dan menggumpal sehingga kenampakannya tidak menarik dan panelis tidak menyukai akan hal itu. Hal ini tidak sesuai dengan pernyataan Siregar (2010) bahwa penambahan GMS tidak mempengaruhi aroma, rasa, dan rasa suatu produk (Siregar, 2010). 


\section{KESIMPULAN}

Terdapat interaksi antara penambahan rumput laut dan gliserol monostearat terhadap kadar serat pangan beras sebesar 1,53\% dan nasi analog sebesar 1,63\% pada perlakuan R3G3 (bubur rumput laut 3\% dan gliserol monostearat $3 \%$, serta kenampakan dan tekstur nasi beras analog. Penambahan rumput laut berpengaruh terhadap kadar air sebesar 6,81\%; kadar abu sebesar 0,55\%; antioksidan beras sebesar 27,35\%; antioksidan nasi sebesar 25,57\%; serat beras sebesar 1,53\%; serat nasi 1,63\%; kenampakan dan tekstur nasi. Penambahan gliserol monostearat berpengaruh terhadap kadar air sebesar 6,54\%; kadar abu sebesar 0,59\%; kadar lemak 1,18\%; kadar karbohidrat 91,78\%; serat beras sebesar 1,53\%; serat nasi 1,63\%; kenampakan nasi, tekstur nasi, rasa nasi, aroma nasi, dan kesukaan pada nasi.

\section{REFERENSI}

Agusman., Apriani, S. N. K., dan Murdinah. 2014. Penggunaan tepung rumput laut Eucheuma cottonii pada pembuatan beras analog dari tepung modified cassava flour (mocaf). Jurnal Perikanan. 9(1):1-10.

Agus, T. S., dan Ardiyati, T. 2009. Aktivitas dan stabilitas radical scavening Laskorbil palmitat hasil sintesis secara enzimatik. Jurnal teknologi industri pangan, Vol XX No. 2.

Andarwulan, N., F. Kusnandar, dan D. Herawati. 2011. Analisis Pangan. PT Dian Rakyat, Jakarta.

Association of Official Analytical and Chemistry. 2005. Official Methode of Analysis. 18th ed. Marylan: Association of Official Analytical Chemist inc.

Badan Pusat Statistik. 2017. Konsumsi Beras Tahun 2017. Jakarta.

Badan Pusat Statistik. 2019. Produksi Beras Tahun 2019. Jakarta.

Budijanto, S. dan Yuliyanti. 2012. Studi Persiapan Tepung Sorgum (Sorghum bicolor L. Moench) dan Aplikasinya pada Pembuatan Beras Analog. Jurnal Teknologi Pertanian. Vol. 13(3): 177-186.

Damat, D., A. Tain, H. Handjani, U. Chasanah dan. D.N. Putri. 2018. Teknologi Pati Termodifikasi dan Manfaatnya bagi Kesehatan. UMM Press.

Damat, D., R. Anggriani, R.H. Setyobudi, P. Soni. 2019. Dietary fiber and antioxidant activity of gluten-free cookies with coffee cherry flour addition. Coffee Science. Vol 14, No 4 (2019): 493-500.

Dewi, E, N., Susanto E. 2011. Alga: Teknologi Pengolahan dan Produk Pengembangannya. BP Undip. Semarang.

Dyah, A., R., Estiasih, T. 2014. Beras Analog Berbasis Umbi Garut (Maranta arundinaceae L) Dan Alginat sebagai Pangan Berkhasiat Obat (Medicinal Food) yang diujikan Pada Tikus Hiperglikemik. Jurnal Pangandan Agroindustri. Vo 4 (2) : 498-504

Fauzi, A. 2017. Karakteristik Beras Tiruan Dengan Penambahan Rumput Laut dan Agar-agar. Bogor. IPB. 
Ferri, M. 2006. Pengaruh cara pengeringan terhadap mutu simplisia sambiroto. Balai Penelitian Tanaman Obat dan Aromatik. Bul. Littro. Vol XIIV No. 1. Hal 1-5.

Ginting, E., Utomo, J., Yulifianti, R., dan Jusuf, M. 2011. Potensi Ubi Jalar Ungu Sebagai Pangan Fungsional. Iptek Tanaman Pangan Vol. 6 No. 1.

Hardian, I., Cahyadi, W., Siti, I. N. 2018. Perbandingan Tepung Sorgum (Sorgum bicolor L. Moench) Dengan Tepung Singkong (Manihot Escolenta) dan Konsentrasi Gliserol Monostearat (GMS) Terhadap Karakteristik Beras Analog Fortifikasi. Jurnal Agriekstensia Vol. 17 No. 2.

Hidayat, R. 2006. Pembuatan Roti Tawar (Kajian Subsitusi Tepung Tapioka dan Penambahan Gliserol Monostearat). Jurnal Teknologi Pangan. Hal : 130 136.

Kaur, M., Oberei, D.P.S. and Sogi, D.S. 2011. Physicochemical, Morphological and Pasting Properties of Acid Treated Starches from Different Botanical Sources. J. Food Sci Technol. 48(4):460-465.

Kuswardani, K., Trisnawati, Y.Ch., dan Faustine. 2008. Kajian Penggunaan Gliserol Monostearat pada Roti Tawar Non Gluten yang Terbuat dari Maizena, Tepung Beras dan Tapioka. Jurnal Teknologi Pangan dan Gizi. Vol. 7(1) : $55-65$.

Lopulalan, C.G.C. (2016). Pengaruh tepung ketan terhadap sifat kimiaa dodol tepung biji durian (Durio zibethinus Murr). Jurnal Agroforesti 11 (3), 195204.

Masli, R., 2007. Studi Pembuatan Tepung Pisang Kepok (Musa paradisiaca forma typical) sebagai Bahan Substitusi Pembuatan Roti Tawar (Kajian Tingkat Kematangan Pisang Kepok dan Suhu Pengeringan). Universitas Muhammadiyah Malang.

Muchtadi, T.R., Sugiyono. 2013. Prinsip dan Proses Teknologi Pangan. Alfabeta: Bandung.

Nawaly, H. Susanto, A. B., Jacob, L. A. U. 2013. Review Senyawa Bioaktif dari Rumput Laut Sebagai Antioksidan. Semarang: Undip.

Noviasari, S., Kusnandar, F., Setiyono, A., dan Budijanto, S. 2017. Karakteristik fisik, kimia, dan sensoris beras analog berbasis bahan pangan non beras. Artikel kimia. Pangan, Vol. 26 No. 1 April $2017: 1$ - 12.

Princestasari, L. D., dan Amalia, L. 2015. Formulasi rumput laut Gracilaria sp. dalam pembuatan bakso daging sapi tinggi serat dan iodium. Jurnal Gizi Pangan, 10(3), 185-196.

Setiawati, N.P., J. Santoso, dan S. Purwaningsih. 2014. Karakteristik Beras Tiruan dengan Penambahan Rumput Laut Eucheuma cottonii Sebagai Sumber Serat Pangan. Jurnal Ilmu dan Teknologi Kelautan Tropis. Vol. 6. No. 1: 197-208

Siregar. 2010. Kualitas Pelayanan Penyuluhan dan Kepuasan Petani dalam Penanganan dan Pengolahan Hasil Ubi Jalar (Ipomoea batatas L.). Jurnal Penyuluhan Pertanian 5(1)

Utami, L.I. 2008. Pengambilan Minyak Kelapa Dengan Proses Fermentasi Menggunakan Sacharoomyces cerevisiae Amobil. Jurnal Penelitian Ilmu Teknik. Vol 8 (2): 86-95 
Widara, S. S. 2012. Studi pembuatan beras analog dari berbagai sumber karbohidrat menggunakan teknologi hot extrusion. Skripsi Fakultas Teknologi Pertanian IPB, Bogor..

Winarno, F. G. 2008. Kimia Pangan dan Gizi. Jakarta: Gramedia Pustaka Utama.

Winarti, S., Karti, E. B. S., Yusuf, F. Z. F. 2017. Karakteristik Mie Kering dengan Substitusi Tepung Gembili dan Penambahan Plastisizer Gliserol Monostearat. Surabaya. UPN Surabaya.

Wonggo, D. 2010. Penerimaan konsumen terhadap selai rumput laut (Kappaphycus alvarezii). J. Perikanan dan Kelautan, 6(1):51-53. 